inadequate mothers (and hence children at risk) during pregnancy. ${ }^{14}$ They showed that women who had been separated from their own parents when they were aged under 11 were more likely than others to have problems with their babies or marriages, and were thus more in need of support.

We acknowledge the help of many people not mentioned in the article who have worked hard with us over many of these cases: family doctors, radiologists, registrars, house physicians, casualty officers, casualty sisters, ward sisters, and others.

We are grateful to the Chief Constable of Derbyshire for giving his approval for publication.

\section{References}

${ }^{1}$ Kempe, C H, et al, fournal of the American Medical Association, 1962, 191, 17.
2 British Paediatric Association, British Medical fournal, 1966, 1, 601.

3 Department of Health and Social Security, The Battered Baby. London, DHSS, 1970.

${ }^{4}$ Department of Health and Social Security, Battered Babies. CMO 10/72. London, DHSS, 1972.

5 British Medical fournal, 1973, 4, 96.

6 British Medical Fournal, 1973, 4, 657.

${ }^{7}$ Franklin, A W (editor), Concerning Child Abuse. Papers Presented by the Tunbridge Wells Study Group on Non-accidental Injury to Children. Edinburgh, Churchill Livingstone, 1975.

${ }^{8}$ Howells, J G, Remember Maria. London, Butterworths, 1974.

9 Godber, G, and Cooper, J, Letter to the Medical Officers of Health and Children's Officers, contained in ref No 2.

10 Davies, H de la Haye, Police fournal, 1971, 44, 193.

11 Identifying and Safeguarding Battered Babies. Royal Borough of Kingston on Thames, London, DDSS/919, 1974.

12 Rogers, D, et al, British Medical fournal, 1976, 1, 796.

13 Smith, S M, and Hanson, R, British Medical fournal, 1974, 3, 666.

14 Frommer, E A, and O'Shea, G, British fournal of Psychiatry, 1973, 123, 149.

\title{
Measurement of cardiac muscle relaxation in hypothyroidism
}

\author{
J J MANNS, A M M SHEPHERD, J CROOKS, D G ADAMSON
}

British Medical fournal, 1976, 1, 1366-1368

\section{Summary}

The isovolumetric relaxation time of the left ventricle (IRT) in 20 hypothyroid patients (133 \pm (SE of mean) $4 \mathrm{~ms}$ ) was significantly longer than that in 23 normal subjects $(95 \pm 3 \mathrm{~ms})$. During a trial of thyroxine replacement the IRT in 12 hypothyroid patients fell from $143 \pm 4 \mathrm{~ms}$ to $107 \pm 4 \mathrm{~ms}$. The IRT seems to be a useful index of endorgan function in hypothyroidism.

\section{Introduction}

Combined apex cardiography and phonocardiography can reliably measure the isovolumetric relaxation of the left ventricle (IRT).1-3 Since relaxation of skeletal muscle is delayed in hypothyroidism, ${ }^{4}$ relaxation of cardiac muscle might also be delayed. We therefore measured the IRT in hypothyroid patients before and after treatment with thyroxine.

\section{Patients and methods}

Apex cardiography was carried out using a hollow bell attached to a piezoelectric transducer. ${ }^{5}$ A phonocardiogram (aortic area) and electrocardiogram (standard lead II) were recorded simultaneously with a multichannel recorder. Ankle reflex time was recorded with a photomotograph. IRT was measured from the major deflection of the aortic component of the second heart sound to the 0-point of the apex cardiogram, which coincides with mitral valve opening (fig 1). ${ }^{1356}$

As part of a preliminary assessment of their thyroid status patients were given a clinical hypothyroid diagnostic score. ${ }^{7}$ Protein-bound iodine levels (PBI; normal 315-630 $\mathrm{nmol} / 1$ 4-8 $\mu \mathrm{g} / 100 \mathrm{ml}$ ), Thyopac-3 index (radiochemical centre, Amersham; normal 90-110\%), serum

Departments of Medicine and Pharmacology and Therapeutics, University of Dundee, Dundee, Scotland

J J MANNS, MB, MRCP, senior registrar, Dundee Teaching Hospitals (now consultant physician, Wythenshawe Hospital, Manchester)

A M M SHEPHERD, BSC, MRCP, research fellow (now lecturer) department of pharmacology and therapeutics

J CROOKS, MD, FRCP, professor of pharmacology and therapeutics

D G ADAMSON, MD, FRCP, consultant physician

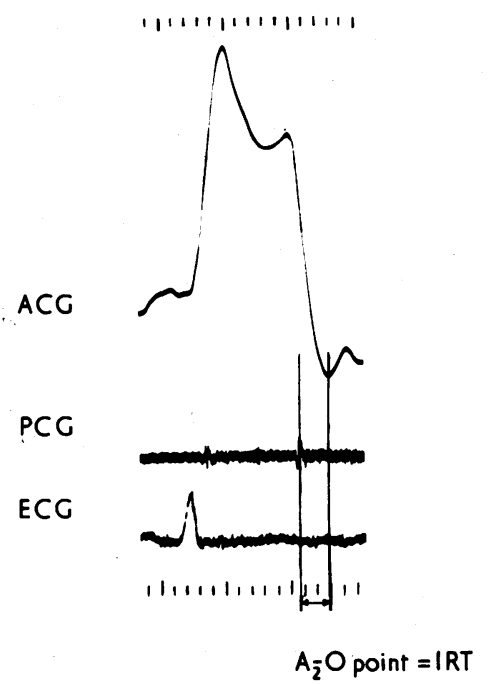

FIG 1-Normal apex cardiogram showing how isovolumetric relaxation of left ventricle was measured. ACG $=$ Apex cardiogram. PCG $=$ Phonocardiogram. ECG = Electrocardiogram.

cholesterol concentrations (normal 3.89-7.77 mmol/1 150-300 mg/100 $\mathrm{ml}$ ), 48-hour ${ }^{131}$ I uptake (normal range $>15 \%$ of dose), and Achilles tendon reflex half-relaxation time (normal range $250-380 \mathrm{msec}^{4}$ were also measured, and the thyrotrophin stimulation test (10 units of thyrotrophin for 3 days) was performed.

Hypothyroidism was diagnosed when two or more indices were abnormal, at least one of the abnormal indices being the thyroid score, PBI concentration, or radioiodine uptake.

Twenty patients diagnosed as hypothyroid according to these criteria were studied (table I). Fifteen of the hypothyroid patients consented to undergo a therapeutic trial of thyroxine. The trial consisted of monthly increments of thyroxine $50 \mu \mathrm{g} /$ day, to a total daily dose of $300 \mu \mathrm{g}$ or until the patient became clinically and biochemically euthyroid. Before each monthly increment every patient was assessed clinically, and 12-lead electrocardiography, ankle jerk tests, apex cardiography, phonocardiography, and standard lead II electrocardiography were performed as described above.

Twenty-three normal subjects were also studied. All were clinically euthyroid with a normal PBI value and Thyopac-3 index and were either ambulant hospital patients with conditions not referable to the thyroid gland or hospital staff (table II). The normal subjects were matched for age, but not sex, with the patients. 
TABLE I-Clinical and biochemical details of 20 patients

\begin{tabular}{|c|c|c|c|c|c|c|c|c|c|c|c|}
\hline $\begin{array}{l}\text { Case } \\
\text { No }\end{array}$ & $\underset{\text { (years) }}{\text { Age }}$ & Sex & Diagnosis & $\begin{array}{l}\text { Thyroid } \\
\text { score }\end{array}$ & $\underset{(\mathbf{n m o l} / \mathbf{l})}{\mathbf{P B I}}$ & T3 index & $\underset{(\mathrm{mmol} / \mathrm{l})}{\text { Cholesterol }}$ & $\begin{array}{l}\text { 4-hour } \\
\text { uptake of } \\
{ }_{131} \text { I }(\%)\end{array}$ & $\begin{array}{l}\text { 48-hour } \\
\text { uptake of } \\
\text { 131I(\%) } \%)\end{array}$ & $\underset{\text { stimulation }}{\text { TSH }}$ & ECG \\
\hline $\begin{array}{r}1 \\
2 \\
3 \\
4 \\
5 \\
6 \\
7 \\
8 \\
9 \\
10 \\
11\end{array}$ & $\begin{array}{l}71 \\
68 \\
65 \\
64 \\
64 \\
64 \\
57 \\
54 \\
52 \\
41 \\
17\end{array}$ & $\begin{array}{l}F \\
F \\
F \\
F \\
M \\
M \\
F \\
M \\
M \\
F \\
F\end{array}$ & $\begin{array}{c}\text { Primary hypothyroidism } \\
\text { ", } \\
", \\
", \\
", \\
", \\
\text { Congenital goitre, }\end{array}$ & $\begin{array}{l}+56 \\
+43 \\
+62 \\
+43 \\
+59 \\
+65 \\
+37\end{array}$ & $\begin{array}{r}<158 \\
221 \\
252 \\
<158 \\
181 \\
<258 \\
<258 \\
<258 \\
<258 \\
<258\end{array}$ & $\begin{array}{l}111 \\
118 \\
114 \\
114 \\
111 \\
117 \\
123 \\
117 \\
115 \\
116 \\
114\end{array}$ & $\begin{array}{c}6.48 \\
\\
5.85 \\
7.02 \\
13.0 \\
12.4 \\
9.82 \\
7.87 \\
4.66\end{array}$ & $\begin{array}{c}10.9 \\
2 \cdot 6 \\
5 \cdot 4 \\
2 \\
4 \cdot 0 \\
1 \cdot 8 \\
4 \cdot 3 \\
4 \cdot 0 \\
3 \cdot 17\end{array}$ & $\begin{array}{c}22 \cdot 75 \\
7 \cdot 1 \\
10 \cdot 5 \\
3 \cdot 2 \\
3 \cdot 0 \\
4 \cdot 0 \\
9 \cdot 8 \\
4 \cdot 0 \\
7 \cdot 36\end{array}$ & $\begin{array}{l}\bar{z} \\
\bar{z} \\
\bar{z} \\
\overline{-} \\
=\end{array}$ & $\begin{array}{l}\text { T-wave inversion } \\
\text { Flat } T \text { wave } \\
\text { T-wave inversion } \\
\text { Flat } T \text { wave } \\
\text { Flat } T \text { wave } \\
\text { Flat } T \text { wave } \\
\text { Flat } T \text { wave } \\
\text { Flat } T \text { wave } \\
\text { Flat } T \text { wave } \\
\text { Flat } T \text { wave }\end{array}$ \\
\hline 12 & 76 & $\mathbf{F}$ & $\begin{array}{l}\text { dyshormonogenesis } \\
\text { Primary hypopituitarism }\end{array}$ & +2 & 189 & 117 & $4 \cdot 87$ & $6 \cdot 6$ & $19 \cdot 3$ & + & $\begin{array}{l}\text { Sinus bradycardia, } \\
\text { right bundle }\end{array}$ \\
\hline 13 & 68 & $\mathbf{F}$ & After radioiodine. & +45 & 299 & 114 & $7 \cdot 12$ & $14 \cdot 7$ & $35 \cdot 0$ & - & $\begin{array}{l}\text { branch block } \\
\text { Flat } S-T \text { segment }\end{array}$ \\
\hline $\begin{array}{l}14 \\
15 \\
16 \\
17 \\
18 \\
19 \\
20\end{array}$ & $\begin{array}{l}60 \\
58 \\
56 \\
51 \\
48 \\
41 \\
54\end{array}$ & $\begin{array}{l}M \\
\text { F } \\
F \\
F \\
F \\
F \\
F\end{array}$ & $\begin{array}{c}" \\
" \\
" \\
"\end{array}$ & $\begin{array}{l}-14 \\
-34 \\
-42 \\
-32 \\
+10 \\
-22 \\
+20\end{array}$ & $\begin{array}{r}268 \\
221 \\
307 \\
173 \\
315 \\
260 \\
<158\end{array}$ & $\begin{array}{l}114 \\
115 \\
110 \\
111 \\
112 \\
116 \\
112\end{array}$ & $\begin{array}{l}6 \cdot 37 \\
8 \cdot 26 \\
6 \cdot 86 \\
7.90 \\
9 \cdot 40 \\
9 \cdot 66\end{array}$ & $\begin{array}{c}3 \cdot 8 \\
10 \cdot 14 \\
3 \cdot 2 \\
1 \cdot 26 \\
13 \cdot 2 \\
1 \cdot 33\end{array}$ & $\begin{array}{c}11 \cdot 6 \\
23 \cdot 27 \\
7 \cdot 4 \\
4 \cdot 74 \\
21 \cdot 6 \\
0 \cdot 79\end{array}$ & $\begin{array}{l}- \\
\overline{-} \\
\overline{-} \\
-\end{array}$ & $\begin{array}{l}\text { Flat } T \text { wave } \\
\text { Flat } T \text { wave } \\
\text { Flat } T \text { wave } \\
\text { T-wave inversion } \\
\text { Flat } T \text { wave } \\
\text { Flat } T \text { wave } \\
\text { Flat } T \text { wave }\end{array}$ \\
\hline
\end{tabular}

Conversion: SI to traditional units-PBI: $1 \mathrm{nmol} / 1 \approx 0.0126 \mu \mathrm{g} / 100 \mathrm{ml}$. Cholesterol: $1 \mathrm{mmol} / 1 \approx 38.6 \mathrm{mg} / 100 \mathrm{ml}$.

TABLE II-Details of control group

\begin{tabular}{|c|c|c|c|c|c|}
\hline $\begin{array}{l}\text { Case } \\
\text { No }\end{array}$ & $\underset{\text { (years) }}{\text { Age }}$ & Sex & Diagnosis & $\underset{(\mathrm{ms})}{\mathrm{IRT}}$ & $\begin{array}{l}\text { Ankle } \\
\text { reflex time } \\
\text { (ms) }\end{array}$ \\
\hline $\begin{array}{l}21 \\
22 \\
23 \\
24 \\
25 \\
26 \\
27 \\
28 \\
29\end{array}$ & $\begin{array}{l}78 \\
69 \\
65 \\
61 \\
50 \\
45 \\
45 \\
38 \\
36\end{array}$ & $\begin{array}{l}F \\
M \\
F \\
M \\
M \\
M \\
F \\
F \\
M\end{array}$ & $\begin{array}{l}\text { Carcinoma of lung } \\
\text { Glaucoma } \\
\text { Thrombophlebitis } \\
\text { Glaucoma } \\
\text { Haematemesis } \\
\text { Septic hand } \\
\text { Chronic renal failure } \\
\text { Valium overdose } \\
\text { Acute coronary } \\
\text { insulficiency }\end{array}$ & $\begin{array}{r}112 \\
95 \\
91 \\
64 \\
73 \\
107 \\
127 \\
112 \\
105\end{array}$ & $\begin{array}{r}87 \\
125 \\
83 \\
85 \\
124 \\
107 \\
137 \\
113\end{array}$ \\
\hline $\begin{array}{l}30 \\
31 \\
32 \\
33 \\
34 \\
35 \\
36 \\
37 \\
38 \\
39 \\
40 \\
41 \\
42 \\
43\end{array}$ & $\begin{array}{l}25 \\
66 \\
65 \\
65 \\
52 \\
48 \\
46 \\
32 \\
25 \\
25 \\
61 \\
58 \\
49 \\
35\end{array}$ & $\begin{array}{l}\mathbf{F} \\
\mathbf{M} \\
\mathbf{F} \\
\mathbf{M} \\
\mathbf{M} \\
\mathbf{F} \\
\mathbf{F} \\
\mathbf{M} \\
\mathbf{M} \\
\mathbf{M} \\
\mathbf{M} \\
\mathrm{F} \\
\mathrm{F} \\
\mathbf{M}\end{array}$ & $\begin{array}{l}\text { Myopathy } \\
\text { Healthy } \\
\text { Healthy } \\
\text { Healthy } \\
\text { Healthy } \\
\text { Healthy } \\
\text { Healthy } \\
\text { Healthy } \\
\text { Healthy } \\
\text { Healthy } \\
\text { Healthy } \\
\text { Healthy } \\
\text { Healthy } \\
\text { Healthy }\end{array}$ & $\begin{array}{r}62 \\
83 \\
93 \\
104 \\
98 \\
94 \\
104 \\
100 \\
87 \\
87 \\
105 \\
87 \\
92 \\
76\end{array}$ & $\begin{array}{r}110 \\
93 \\
96 \\
105 \\
120 \\
113 \\
118 \\
87 \\
116 \\
100 \\
200 \\
99\end{array}$ \\
\hline
\end{tabular}

\section{Results}

The mean IRT ( \pm SE of mean) of the control group was $95 \pm 3$ $\mathrm{ms}$, whereas that of the hypothyroid patients was $133 \pm 4 \mathrm{~ms}$ (fig 2). The difference between the mean values of these two groups was highly significant $(P<0.001)$. In only two hypothyroid patients was the initial IRT within the normal range, both were clinically euthyroid.

Therapeutic replacement trial-Three of the 15 patients failed to complete the trial, two because they developed angina pectoris and one because she developed congestive cardiac failure when the dose of thyroxine was increased to $200 \mu \mathrm{g} /$ day. Before treatment the IRT of the 12 patients who completed the trial was $143 \pm 4 \mathrm{~ms}$, and this fell to $107 \pm 4 \mathrm{~ms}$ after the trial. This change was also highly significant $(\mathrm{P}<0.01)$. Nine patients progressed to a thyroxine dose of $300 \mu \mathrm{g} /$ day (table III). Fig 3 shows that the reduction in the IRT in these nine patients became significant at the $5 \%$ level after the patients had received $100 \mu \mathrm{g}$ thyroxine a day for one month and that there was no further fall in the IRT above a dose of $150 \mu \mathrm{g}$ thyroxine a day. The half relaxation time of the ankle jerk in the hypothyroid group was $204 \pm 25 \mathrm{~ms}$ and in the control group $111 \pm 6 \mathrm{~ms}(\mathrm{P}<0.01)$.

\section{Discussion}

There are few useful methods for measuring end-organ function in thyroid disease; the only reliable method generally used is measurement of ankle jerk relaxation time, ${ }^{4}$ although this has limited diagnostic value in many cases. ${ }^{8}$

Apex cardiography is the most direct non-invasive method of measuring isovolumetric ventricular relaxation readily available,

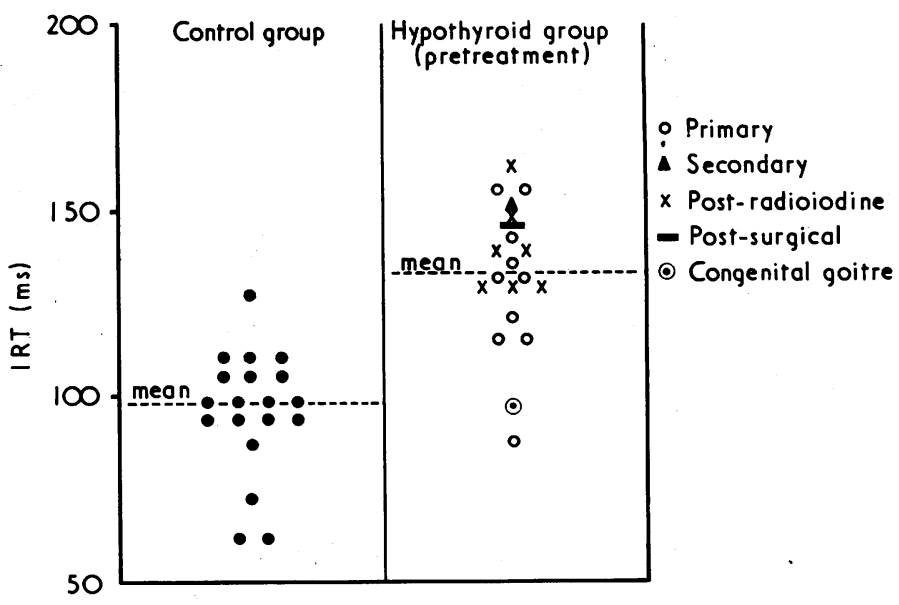

FIG 2-Isovolumetric relaxation times in controls (mean $95 \pm 3 \mathrm{~ms}$ ) and hypothyroid patients (mean $133 \pm 4 \mathrm{~ms}$ ).

TABLE III-Isovolumetric relaxation times $(m s)$ in hypothyroid patients in thyroxine trial

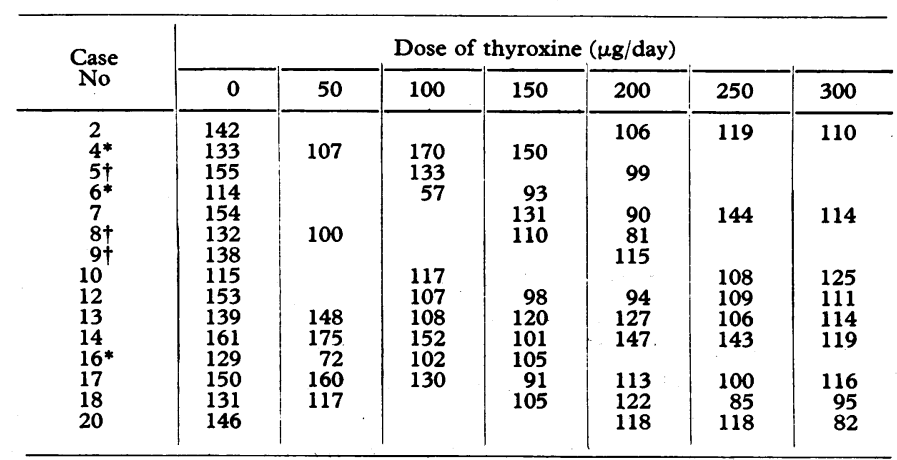

* Cardiac embarrassment on thyroxine $200 \mu \mathrm{g} /$ day.

† Euthyroid on thyroxine $200 \mu \mathrm{g} /$ day.

and it reliably reflects the timing of intracardiac events. ${ }^{1-3} 56$ Heart rate and intravenous ouabain ${ }^{6}$ influence IRT. In our patients heart rate did not change significantly throughout the study and our results were unchanged when corrected with a rate correction formula. ${ }^{\circ}$ Only one of our patients was taking digoxin and she continued to take it throughout the study. Increasing age has also been said to prolong IRT, ${ }^{10}$ although other work has not confirmed this. ${ }^{6}$ There was no significant difference related to age in the IRT values of the control group. 


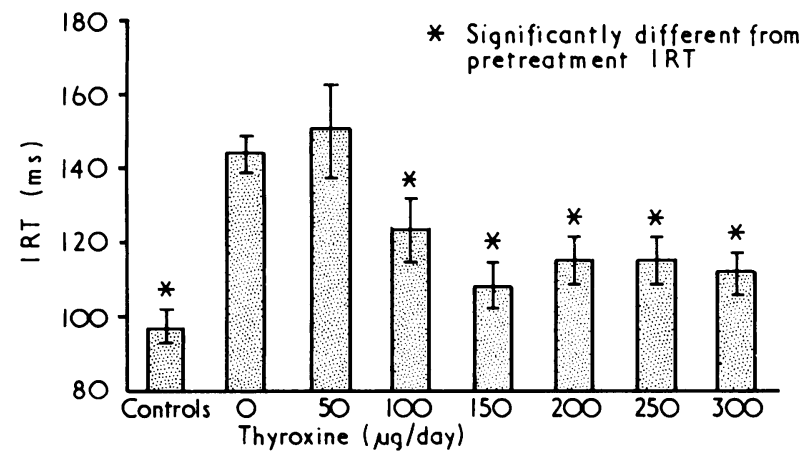

FIG 3-Mean isolvolumetric relaxation times ( $t$ SE of mean) in nine patients with hypothyroidism who progressed to dose of $300 \mu \mathrm{g} /$ day during trial.

Benchimol and Dimond et al in their study of the apex cardiogram in ischaemic heart disease made no reference to abnormalities of the IRT.11

Our results show that the IRT is prolonged in hypothyroid patients and reverts to normal after thyroxine replacement treatment. Since there was no radiographic or clinical evidence of pericardial effusion in any of our patients, we may have been measuring the effect of myxoedematous infiltration of the muscle fibres (a finding first reported in $1880^{12}$ ), and possibly this infiltration no longer causes detectable change in the IRT when the patient is rendered euthyroid.

It is particularly interesting that there was no reduction in the IRT when the dose of thyroxine was increased above $150 \mu \mathrm{g} / \mathrm{day}$, as this finding correlates well with work showing that most hypothyroid patients became euthyroid, using the serum thyrotrophin level as a criterion, on 100-200 $\mu \mathrm{g}$ /day of thyroxine and may be hyperthyroid when on the accepted full replacement regimen of $300 \mu \mathrm{g}$ !day of thyroxine. ${ }^{13}$

There is at present no readily available clinical or biochemical test that indicates the gradual return to normal body metabolism with increasing doses of thyroxine and, in particular, none that show normal end-organ function on less than the full replacement dose of $300 \mu \mathrm{g} /$ day. The IRT as an index of end-organ function in hypothyroidism therefore seems to have great potential as both a research and a diagnostic tool in thyroid disease.

We are grateful to the department of cardiology for their technical help and for use of their equipment.

Requests for reprints should be addressed to Dr A M M Shepherd, Department of Pharmacology and Therapeutics, The University, Dundee, Scotland.

\section{References}

${ }^{1}$ Benchimol, A, and Dimond, E G, American fournal of Cardiology, 1963, $12,368$.

2 Benchimol, A, Dimond, E G, and Carson, J C, American Heart fournal, 1961, 61, 485

${ }^{3}$ Legler, J F, Benchimol, A, and Dimond, E G, British Heart fournal, 1963, 25, 246.

${ }^{4}$ Nuki, G, and Bayliss, R I S, Postgraduate Medical fournal, 1968, 44, 97

5 Coulshed, N, and Epstein, E J, British Heart Fournal, 1963, 25, 697.

${ }^{6}$ Benchimol, A, and Ellis, J G, American fournal of Cardiology, 1967, 19, 196.

${ }^{7}$ Billewicz, W Z, et al, Quarterly fournal of Medicine, 1969, 38, 255.

8 Simpson, G M, Blair, J H, and Nartowicz, G R, New York State fournal of Medicine, 1963, 63, 1148

9 Jezek, V, Sbornik Lekarsky, 1961, 63, 313.

10 Harrison, T R, et al, American Heart fournal, 1964, 67, 189.

11 Benchimol, A, and Dimond, E G, British Heart fournal, 1962, 24, 581.

12 Ord, W M, Transactions of the Clinical Society of London, 1880, 13, 15.

13 Evered, D, et al, British Medical fournal, 1973, 3, 131.

\title{
Relation between blood pressure, weight, and plasma sugar and serum insulin levels in schoolchildren aged 9-12 years in Westland, Holland
}

\author{
C DU V FLOREY, S UPPAL，C LOWY
}

British Medical fournal, 1976, 1, 1368-1371

\section{Summary}

In 2388 schoolchildren aged 9-12 years who took part in a study of cardiovascular risk factors in Westland, Holland, plasma sugar concentrations were found to be positively correlated with systolic and diastolic blood pressure, independently of weight. Serum cholesterol levels were also related to systolic blood pressure in boys, but much less strongly than plasma sugar levels. The relation between serum insulin and blood pressure, independent of plasma sugar, was weak. The relation between plasma

St Thomas's Hospital Medical School, London SE1

C du V FLOREY, MD, senior lecturer, department of community medicine C LOWY, MRCP, senior lecturer, department of chemical pathology

Department of Cardiology, University Hospital, Leiden, the Netherlands

S UPPAL, MD, consultant cardiologist sugar and systolic pressure existed for both sexes and regardless of whether measurements were made in the morning or afternoon; its association with diastolic pressure was weaker, and was not so consistent over all groups. These findings suggest that the relations between risk factors for coronary heart disease that exist in adults are already evident in childhood.

\section{Introduction}

The epidemiology of coronary heart disease (CHD) has been studied extensively in adults. People with raised serum cholesterol levels, blood pressure, and probably body weight are more likely than those with normal levels to have evidence of myocardial ischaemia at the time of the measurement or to suffer overt clinical CHD in the future. Raised blood sugar concentrations (measured after an oral glucose challenge) have also been strongly suggested as a risk factor for CHD but have attracted far less attention than the factors already mentioned.

Reasons for considering raised blood sugar as a precursor of CHD have been well reviewed by Epstein. ${ }^{1}$ Necropsy, clinical, and laboratory studies over the past 50 years have mostly 